\title{
Pengembangan Aplikasi Penerimaan Peserta Didik Baru Berbabasis Zonasi
}

\author{
Khairil $^{1}$, Ricky Zulfiandry ${ }^{2}$ \\ ${ }^{1}$ Dosen Tetap Program Studi Sistem Informasi Fakultas Ilmu Komputer Universitas Dehasen Bengkulu \\ Jl. Meranti Raya No. 32 Kota Bengkulu 38228 Telp. (0736) 22027, 26957 Fax. (0736) 341139; \\ e-mail: Khairil35@gmail.com \\ 2, Dosen Tetap Program Studi Sistem Informasi Fakultas Ilmu Komputer Universitas Dehasen Bengkulu \\ Jl. Meranti Raya No. 32 Kota Bengkulu 38228 Telp. (0736) 22027, 26957 Fax. (0736) 341139 \\ e-mail: ricky.zulfiandry@unived.ac.id
}

\begin{abstract}
The zoning system implemented by the Ministry of Education and Culture in the process of new student admissions (PPDB) in schools aims to equalize the right to education for school-age children. The purpose of this study was to build a Zoning-Based New Student Admissions application at SMP Negeri 6 Bengkulu City. The methods used in this research are interview method, literature study, analysis, system design, testing, and implementation. The system presented is in the form of zoning data input, new student candidate scores, national exam score data, while the process menu is the process menu for determining the assessment of new prospective students. The resulting output is a new student registration report and a new student report that is accepted

Keyword: Applications, Students, Zoning Bases.
\end{abstract}

Intisari- Sistem zonasi yang diterapkan Kemdikbud dalam proses Penerimaan Peserta Didik Baru (PPDB) di sekolah bertujuan untuk pemerataan hak memperoleh pendidikan bagi anak-anak usia sekolah. Tujuan Penelitian ini adalah membangun aplikasi Penerimaan Peserta Didik Baru pada SMP Negeri 6 Kota Bengkulu Berbasis Zonasi. Metode yang digunakan dalam penelitian ini adalah metode wawancara, study pustaka, analisis, perancangan sistem, uji coba, dan implementasi. Sistem yang disajikan berupa input data zonasi, nilai calon siswa baru, data nilai ujian nasional, sedangkan untuk menu proses merupakan menu proses penentuan penilaian calon siswa baru. Untuk output yang dihasilkan adalah laporan pendaftaran siswa baru dan laporan siswa baru yang diterima

Kata Kunci: Aplikasi, Peserta Didik, Basis Zonasi .

\section{PENDAHULUAN}

Mulai tahun 2017-2018, pemerintah menetapkan sistem zonasi untuk proses penerimaan siswa baru. Sistem zonasi yang diterapkan Kemdikbud dalam proses Penerimaan Peserta Didik Baru (PPDB) di sekolah bertujuan untuk pemerataan hak memperoleh pendidikan bagi anak-anak usia sekolah. Sistem zonasi diperuntukan bagi siswa yang memiliki radious zona terdekat sebesar $90 \%$ (sembilan puluh persen) yang di utamakan bagi calon peserta didik miskin, dan yang lainnya disesuaikan dengan nilai ujian berstandar Nasional.

Pesatnya perkembangan di bidang teknologi informasi dan komunikasi sangat mempengaruhi kehidupan masyarakat di berbagai bidang. Hampir semua instansi pemerintah dan perusahaan swasta memanfaatkan peralatan teknologi informasi dan komunikasi untuk membantu dalam menyelesaikan pekerjaan dengan cepat. Begitu juga dalam dunia pendidikan dari tingkat SD sampai dengan Perguruan Tinggi yang sekarang ini sudah banyak yang memanfaatkan teknologi informasi tersebut untuk membantu dalam menyelesaikan pekerjaannya, seperti halnya pekerjaan untuk penerimaan siswa baru.

\section{LANDASAN TEORI}

Basis data atau Database terdiri atas 2 kata, yaitu Basis dan Data. Basis merupakan markas atau gudang, tempat bersarang/berkumpul. Sedangkan Data adalah refresenasi fakta dunia nyata yang mewakili suatu objek seperti manusia (pegawai, siswa, pembeli, pelanggan), barang, hewan, peristiwa, konsep, keadaan, dan sebagainya. Yang diwujudkan dalam bentuk angka, huruf, symbol, teks, bunyi atau kombinasinya [1]. Data Flow Diagram (DFD) atau dalam bahasa Indonesia menjadi Diagram Alir Data (DAD) adalah representasi grafik yang menggambarkan aliran informasi dan transformasi informasi yang diaplikasikan sebagai data yang mengalir dari masukan (input) dan keluaran (output) [2]. ERD merupakan suatu model jaringan yang menggunakan susunan data yang disimpan pada sistem secara abstrak. ERD juga menggambarkan hubungan antara satu entitas yang memiliki sejumlah atribut dengan entitas yang lain dalam 
suatu sistem yang terintegrasi. ERD digunakan oleh perancang sistem untuk memodelkan data yang nantinya akan dikembangkan menjadi basis data (database). Model data ini juga akan membantu pada saat melakukan analisis dan perancangan basis data, karena model data akan menunjukkan beramacam-macam data yang dibutuhkan dan hubungan antardata. ERD merupakan model konseptual yang dapat mendeskripsikan hubungan antara file yang digunakan untuk memodelkan struktur data serta hubungan antardata [3]. Visual Basic selain disebut sebagai bahasa pemrograman (language program), juga sering disebut sebagai sarana ( $\mathrm{Tool}$ ) untuk menghasilkan program-program aplikasi bebasis windows [4]. Secara umum ada beberapa manfaat yang diperoleh dari pemakaian program visual basic, antaranya :

a. Dipakai dalam membuat program-program aplikasi bebasis windows,

b. Dipakai dalam membuat obyek-obyek pembantu program seperti fasilitas help, control active, aplikasi internet, dan sebagainya,

c. Digunakan untuk menguji program (Debugging) dan menghasilkan program akhir EXE yang disebut executable, atau dapat langsung dijalankan.

\section{III.Metode Penelitian}

Adapun metode penelitian yang digunakan adalah metode pengembangan sistem. Pengembangan sistem ini dilakukan untuk pembuatan aplikasi. Dengan adanya aplikasi ini diharap memberikan kemudahan dan efisiensi waktu kepada sekolah dalam proses menentukan siswa yang akan diterima sekolah sesuai dengan jarak tempat tinggal siswa dengan sekolah.

Model pengembangan sistem yang digunakan yaitu Waterfall model. Waterfall model adalah model SDLC (software development life cycle) pengembangan sistem dengan pendekatan alur hidup perangkat lunak secara sekuensial atau terurut dimulai dari analisis, desain, pengodean, pengujian, dan tahap pendukung (support). Berikut adalah gambar model air terjun :

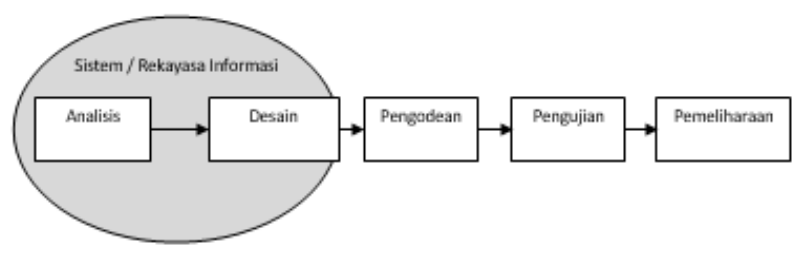

\section{Gambar 1. Model pengembangan sistem}

a. Analisis kebutuhan perangkat lunak

Sistem yang dikembangkan merupakan untuk. memberikan kemudahan pada sekolah. Kebutuhan aplikasi pada pengembangan sistem ini sesuai dengan pemakai aplikasi.

b. Desain

Desain sistem adalah langkah - langkah yang fokus pada desain pembuatan aplikasi. Termasuk desain struktur data, arsitektur perangkat lunak, representasi antarmuka, dan prosedur pengkodean.

c. Pembuatan kode program

Desain harus ditranslasikan ke dalam program untuk menghasilkan aplikasi. Hasil dari tahap ini adalah program komputer sesuai desain yang telah dibuat pada tahap desain.

d. Pengujian

Pengujian pada aplikasi ini secara logika dan fungsi dan memastikan bahwa semua bagian sudah diuji. Hal ini untuk meminimalisir kesalahan (error) dan memastikan keluaran yang dikeluarkan sesuai dengan yang diinginkan.

e. Pemeliharaan

Aplikasi penerimaan peserta didik berdasarkan zonasi ini yang sudah diimplementasikan sekolah pasti akan mengalami perubahan. Perubahan tersebut bisa karena mengalami kesalahan karena harus menyesuaikan dengan lingkungan (system operasi baru) .

\section{IV.Hasil dan Pembahasan}

Implementasi Aplikasi Penerimaan Peserta Didik Baru pada SMP Negeri 6 Kota Bengkulu Berbasis Zonasi berjalan setelah aplikasi ini di install. Data base yang digunakan dalam penelitian ini adalah Microsoft Access dan menggunakan Visual Basic 6.0 dalam pembuatan 
programnya, yang dapat berjalan dalam sistem operasi Windows. Aplikasi ini terdiri dari beberapa menu, tampilannya seperti pada gambar 2 .

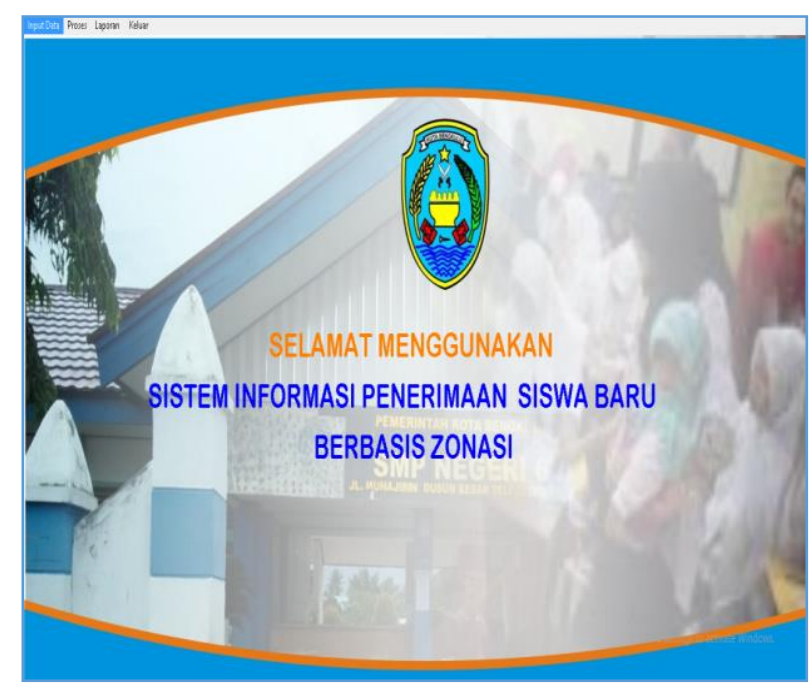

Gambar 2. Menu Utama Aplikasi

Tampilan menu pendaftaran penerimaan peserta didik baru yang terdiri dari input Nomor pendaftaran, kode zonasi dan wilayah, tanggal pendaftaran, NISN, nama calon siswa, jenis kelamin, tempat lahir, tanggal lahir, alamat jalan, RT, RW, kecamatan, asal sekolah, nomor induk keluarga, tahun terbit. Input Nomor pendaftaran merupakan atribute key yang digunakan untuk menampilkan kembali atribut yang telah tersimpan dalam database. Tampilan Menu Input Data daftar penerimaan siswa baru dapat dilihat pada Gambar 3.

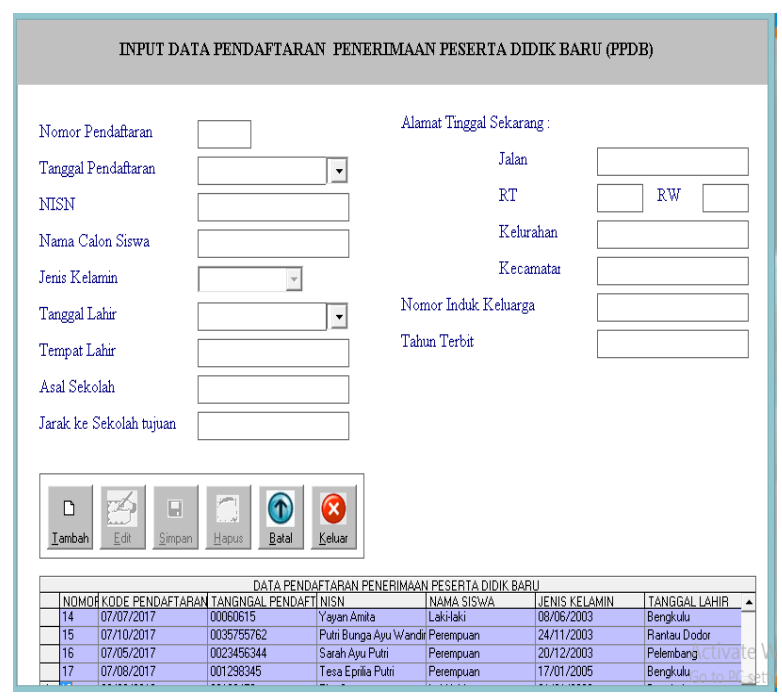

Gambar 3. Input Pendaftar Peserta Didik berdasarkan jarak ke sekolah

Tampilan menu Input Data nilai ujian nasional berisikan input Nomor Pendaftaran, nama pendaftar, nilai bahasa Indonesia, nilai Matematika, nilai IPA dan jumlah nilai. Atribute nomor pendaftaran merupakan field kunci yang digunakan untuk menampilkan kembali field-field yang telah tersimpan dalam database seperti pada gambar 4.

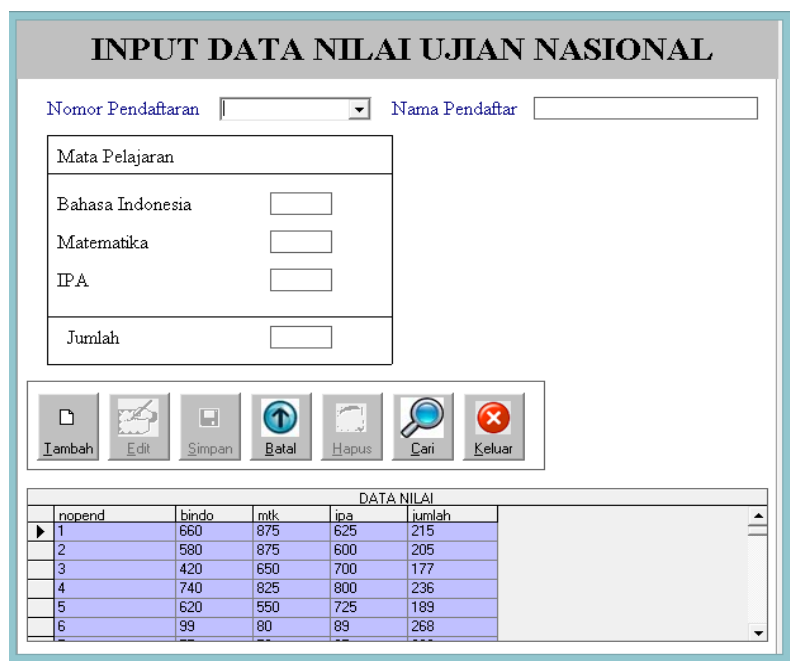

Gambar 4. Input nilai ujian nasional siswa

Proses penentuan penerimaan siswa baru merupakan informasi untuk menampilkan informasi siswa yang diterima berdasarkan zonasi yang sesuai dengan tempat tinggal siswa. Input data ini berdasarka nomor regrestasi, nama calon siswa, wilayah zonasi, jumlah nilai ujian nasional, quota dan keputusan.

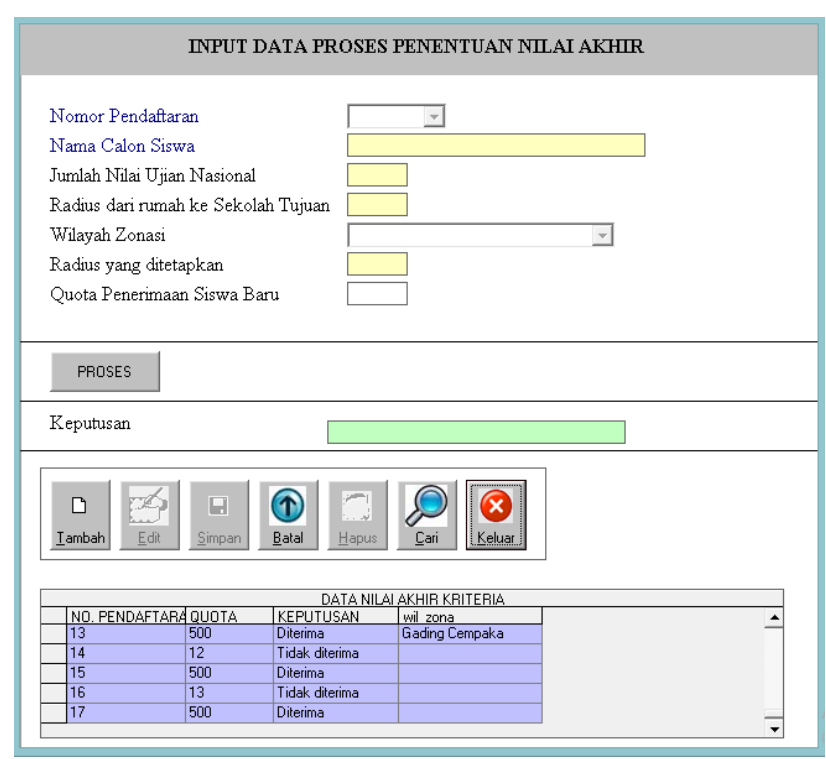

Gambar 5. Input penentuan hasil penerimaan siswa berdasarkan zonasi

Pada aplikasi ini terdiri dari dua laporan yaitu laporan perserta didik yang mendaftar di sekolah, dan laporan 
peserta didik yang diterima sesuai dengan zonasi siswa, gambar 6 merupakan berntuk laporannya.

\begin{tabular}{|c|c|c|c|c|c|c|c|c|c|c|c|c|}
\hline \multicolumn{13}{|c|}{ 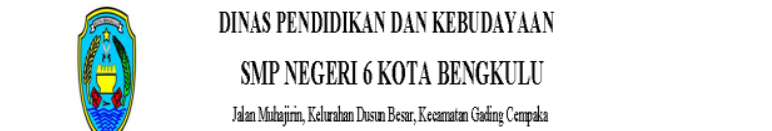 } \\
\hline \multicolumn{13}{|c|}{ 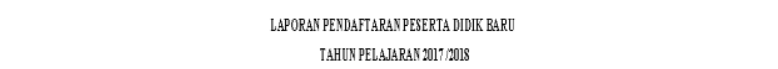 } \\
\hline \multirow{2}{*}{ Ho. } & \multirow{2}{*}{ Punatr } & \multirow{2}{*}{ 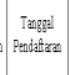 } & \multirow{2}{*}{ NEN } & \multirow{2}{*}{$\begin{array}{c}\text { Namaciln } \\
\text { Sisme }\end{array}$} & \multirow{2}{*}{$\begin{array}{l}\text { feais } \\
\text { Retrin } \\
\end{array}$} & \multirow{2}{*}{$\begin{array}{l}\text { Telat } \\
\text { Lats }\end{array}$} & \multirow{2}{*}{$\begin{array}{l}\text { Traggal } \\
\text { Latir }\end{array}$} & \multicolumn{3}{|r|}{ Alent } & \multirow{2}{*}{ 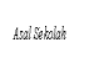 } & \multirow{2}{*}{ Whis } \\
\hline & & & & & & & & Jibn & $R I R T$ & \begin{tabular}{l|l}
7 & Vexandian
\end{tabular} & & \\
\hline 1 & 1 & 0.1.0.2.217 & outs:3012 & 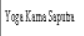 & i & Bryghth & 9.1.5.2044 & 4 Andint 6 & \begin{tabular}{l|l}
1 & 2
\end{tabular} & Sighosurhit & 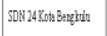 & 25,50 \\
\hline 2 & 2 & 0.0.-2.2n & outs:3014 & 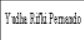 & i & Bysth & 19.0.2.204 & 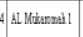 & 104 & 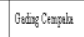 & 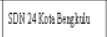 & $25 x$ \\
\hline 3 & 3 & 0.0.0.2017 & corsass & Punam & l & Bryghth & 31.1.2.2015 & 8 Cosplinh & 103 & silber & 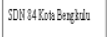 & $m$ \\
\hline 4 & 4 & a.r.a.2.17 & 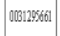 & Ywa & 8 & Bryghth & 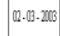 & 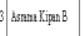 & is 5 & Siggarulif & 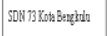 & 20,0 \\
\hline 5 & 3 & 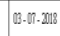 & outsenso & 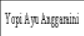 & P & Builfom & 16.-10.2004 & 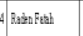 & \begin{tabular}{|l|l|}
5 & 1 \\
\end{tabular} & Sowisinet & 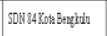 & (a) \\
\hline 6 & 6 & a.r.2.2017 & 10r7somes & hag ongas & l & Begrith & 0.0.20.210 & 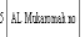 & 155 & Singsurphit & 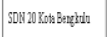 & mand \\
\hline$?$ & 1 & a.0.0.2017 & ontersine & Fins & P & Begrth & 17.2.2.2014 & 4 | Mapisis! & ns & Sigranghit & 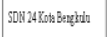 & 2800 \\
\hline 8 & 8 & 12.6-2.2017 & onomens & ini & P & Bergoroun & 12.6.6.2185 & 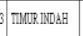 & \begin{tabular}{|l|l}
8 & 3 \\
\end{tabular} & 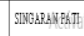 & 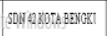 & 20,0 \\
\hline
\end{tabular}

Gambar 6. Laporan peserta didik yang mendaftar

Sedangkan laporan calon peserta didik baru yang diterima disekolah adalah seperti pada gambar 7 .

\begin{tabular}{|c|c|c|c|c|c|c|c|c|c|c|c|}
\hline \multicolumn{12}{|c|}{ 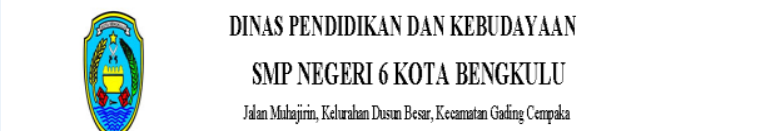 } \\
\hline \multicolumn{12}{|c|}{ 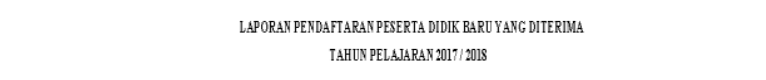 } \\
\hline \multirow{2}{*}{ No. } & \multirow{2}{*}{ Penoror } & \multirow{2}{*}{$\begin{array}{l}\text { Tongal } \\
\text { Penilatrax }\end{array}$} & \multirow{2}{*}{ MIS } & \multirow{2}{*}{ Nama Calm Sisiva } & \multirow{2}{*}{ Jemis } & \multirow{2}{*}{ Tement Latir } & \multirow{2}{*}{$\begin{array}{l}\text { Tangal } \\
\text { Latir }\end{array}$} & \multicolumn{3}{|c|}{ Alenat } & \multirow{2}{*}{ 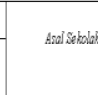 } \\
\hline & & & & & & & & Jiben & $R R_{R T}$ & 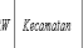 & \\
\hline 1 & 1 & (3.9.1.2.210 & outsars & 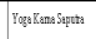 & 1 & Beghith & 3.1.2.2014 & Ansitio & 132 & Sageuphis & 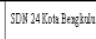 \\
\hline 2 & 2 & (30.91.20179 & 0.4523204 & 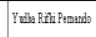 & 1 & Benghit & 19.19.204 & AL Wharmal 1 & 104 & Gatys Compin & 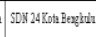 \\
\hline 3 & 3 & (3.-10.2817) & wos:3025s & \begin{tabular}{|l} 
Yunuthats \\
\end{tabular} & 1 & Beghtit & 11.12.2813 & Ramglinith & 105 & sother & 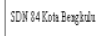 \\
\hline 4 & 4 & (x.-10.2017) & Dosilessal & Prus & p & Begpint & 10.0.20.2010 & Asmanh Xipan & 155 & Sigen Prit & 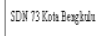 \\
\hline 3 & $s$ & (3.0.0.21813 & 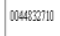 & 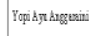 & P & Bü5ur & 16.0.20.204 & $\begin{array}{l}\text { Riminfith } \\
\end{array}$ & $\begin{array}{lll}5 & 1 \\
\end{array}$ & Sugrisent & 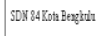 \\
\hline 6 & 6 & 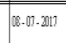 & 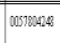 & 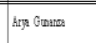 & 1 & Benghth & (01.10.2005 & AL Wuarman & 0155 & Sagereptif & 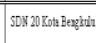 \\
\hline 1 & $?$ & (x.9.12.210 & oussersun & Fin Fhtharati & ? & Beghth & 17.0.20.204 & Mangsis 1 & 205 & Sagereptit & 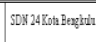 \\
\hline 8 & 10 & (19-10.-21017 & wos31654 & 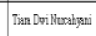 & 8 & Benghtit & 21.0.-2015 & \begin{tabular}{|l} 
Padk \\
\end{tabular} & 114 & Stethr & 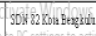 \\
\hline
\end{tabular}

Gambar 7. Laporan Peserta Didik yang Diterima.

\section{KESIMPULAN}

Berdasarkan hasil pembahasan dan pengujian diperoleh kesimpulan sebagai berikut : Aplikasi penerimaan peserta didik baru pada sekolah berbasis zonasi dibuat dengan sistem basis data sebuah program dalam hal ini menggunakan yang memungkinkan pengguna untuk dapat mengakses data file-file pada aplikasi ini. Output dari aplikasi ini menampilkan siswa yang dapat diterima disekolah sesuai dengan zonasi tempat tinggal siswa dengan perhitungan jarak tempat tinggal siswa ke sekolah tujuan. Pemodelan sistem dalam pengembangan aplikasi ini dengan mengembangkan aliran data yang akan diproses menjadi informasi dan aliran distribusi yang dibuat secara sederhana dengan menggunakan Diagram Kontek, Diagram Arus Data (DFD) dari level 0 sampai level 3.

\section{Daftar Pustaka}

[1] Fathansyah, 2012, Basis Data : Informatika, Bandung.

[2] Mulyana, 2009, Sistem Informasi Konsep\& Aplikasi : Pustaka Pelajar, Yogyakarta.

[3] Shalahuddin, 2011, Modul Pembelajaran Rekayasa Perangkat Lunak: Modula, Bandung.

[4] Subari dan Susanto, 2008, Pandung Lengkap Pemrograman Visual Basic 6.0 : Cerdas Pusaka Publiser, Jakarta.

[5] Sutarbi, 2012, Analisis Sistem Informasi : Andi Ofset, Yogyakarta.

[6] Yakub, 2012, Pengantar Sistem Informasi : Graha Ilmu, Yogyakarta. 